\title{
Brome Control and Microbial Inoculation Effects in Reclaimed Cool-Season Grasslands
}

\author{
M. Dean Stacy, ${ }^{1}$ Barry L. Perryman, ${ }^{2}$ Peter D. Stahl, ${ }^{3}$ \\ and Michael A. Smith ${ }^{4}$ \\ Authors are ${ }^{1}$ Range Management Specialist, USDA-NRCS, Price, UT 84501; ${ }^{2}$ Assistant Professor, \\ Department of Animal Biotechnology, University of Nevada-Reno, Reno, NV 89557; ${ }^{3}$ Assistant Professor and \\ ${ }^{4}$ Professor, Department of Renewable Resources, University of Wyoming, Laramie, WY 82071.
}

\begin{abstract}
Introduction and subsequent invasion of smooth brome (Bromus inermis Leyss.) into native cool- and warm-season grassland communities has become problematic where presence of native species is important or mandated. The objectives of this study were to examine the efficacy of burning, grazing, and herbicide to reduce smooth brome production and cover while minimizing coincident detrimental effects on cool-season grasses in a reclaimed surface coal mine site. Concurrently, the project also investigated effects of microbial inoculation on respread topsoil subjected to long-term storage and associated effects on seeded cool-season grasses subjected to brome control treatments. Results indicated that grazing and burning were most effective after 2 years of treatment. Smooth brome biomass was lowest in reburned cells (mean \pm SE, $189 \pm 77 \mathrm{~kg} \cdot \mathrm{ha}^{-1}$ ) followed by regrazed $(294 \pm 129)$ compared to untreated cells $(824 \pm 42)(P<0.0001)$. Native grass production was highest in grazed cells $(141 \pm$ $\left.67 \mathrm{~kg} \cdot \mathrm{ha}^{-1}\right)$ followed by burning $(104 \pm 41)$, herbicide $(72 \pm 30)$, and untreated $(30 \pm 27)$. Foliar cover response patterns were similar. Inoculation had little effect on microbial biomass and mycorrhizal infection. Retreated cells did show differences among months $(P=0.013)$ in 2000 , and microbial carbon ranged from $0.07 \pm 0.01 \mathrm{mg} / \mathrm{g}$ in June to $0.12 \pm 0.01$ in July and $0.12 \pm 0.01$ in August, averaged across treatments. Root infection decreased as soil moisture declined. Results indicate grazing offers the greatest potential for controlling smooth brome without harming native, seeded grasses on reclaimed lands in northern mixedprarie communities, and inoculation was unnecessary for enhancing seeded, cool-season grass growth.
\end{abstract}

\section{Resumen}

La introducción y subsecuente invasión del "Smooth brome" (Bromus inermis Leyss.) en la comunidades de pastizal de zacates de estación fría y caliente ha venido a ser problemático donde la presencia de las especies nativas es importante o mandatoria. Los objetivos de este estudio fueron examinar la eficacia de la quema, el apacentamiento y los herbicidas para reducir la producción y cobertura del "Smooth brome" minimizando los efectos perjudiciales colaterales sobre los zacates de estación fría en un sitio en restauración de una mina superficial de carbón. El proyecto también examinó los efectos de la inoculación microbiana sobre el suelo de la capa superficial esparcido en el sitio después de un largo periodo de almacenamiento y los efectos asociados en zacates de estación fría sembrados y sujetos a tratamientos de control de "Smooth brome." Los resultados indican que el apacentamiento y la quema fueron más efectivos después de dos años de tratamiento. La menor biomasa de "Smooth brome" se obtuvo en las áreas re-quemadas (media $\pm \mathrm{EE}, 189 \pm 77 \mathrm{~kg} \cdot \mathrm{ha}^{-1}$ ), seguida por las áreas re-apacentadas $(294 \pm$ $\left.129 \mathrm{~kg} \cdot \mathrm{ha}^{-1}\right)$ comparados con las áreas sin tratar $\left(824 \pm 42 \mathrm{~kg} \cdot \mathrm{ha}^{-1}\right)(P<0.0001)$. La mayor producción de biomasa de los zacates nativos se obtuvo en las áreas apacentadas $\left(141 \pm 67 \mathrm{~kg} \cdot \mathrm{ha}^{-1}\right)$, seguida por las áreas quemadas, con aplicación de herbicidas y sin tratar con $104 \pm 41,72 \pm 30$ y $30 \pm 27 \mathrm{~kg} \cdot \mathrm{ha}^{-1}$ respectivamente. Los patrones de respuesta de la cobertura foliar fueron similares. La inoculación tuvo poco efecto en la biomasa microbiana y la infección de micorrizas. En el 2000, las áreas re-tratatadas mostraron diferencias entre meses $(P=0.013)$ y el carbón microbiano, promediado entre tratamientos, varió de $0.07 \pm 0.01 \mathrm{mg} / \mathrm{g}$ en Junio a $0.12 \pm 0.01$ en Julio y $0.12 \pm 0.01$ en Agosto. La infección radical disminuyó conforme la humedad del suelo disminuyó. Los resultados indican que el apacentamiento ofrece el mayor potencial para controlar el "Smooth brome" sin dañar a los zacates nativos sembrados en sitios en restauración de las comunidades de praderas mixtas del norte y la inoculación fue innecesaria para mejorar el crecimiento de los zacates de estación fría sembrados.

Key Words: cool-season grasses, grazing, prescribed fire, microbial biomass, mycorrhizae

\section{INTRODUCTION}

Research was funded by the Pittsburg \& Midway Mining Company.

Correspondence: Dr Barry Perryman, Dept of Animal Biotechnology, University of Nevada-Reno, MS202 Reno, NV 89557 Email: bperryman@cabnr.unr.edu

Manuscript received 24 January 2003; manuscript accepted 1 July 2004.
Smooth brome (Bromus inermis Leyss.), an introduced coolseason perennial grass, invades both native cool- and warmseason grasslands throughout North America (Dibbern 1947; Willson 1991; Stubbendieck et al. 1994). Invasion and persistence of smooth brome has made its control a particular problem for land managers of the remnant tallgrass prairies 


\begin{tabular}{|l|l|l|l|}
\hline C & BWI & G & H \\
\hline B & GWI & CWI & HWI \\
\hline
\end{tabular}

\begin{tabular}{|l|l|l|l|} 
Block 2 \\
\hline CWI & HWI & H & B \\
\hline GWI & C & G & BWI \\
\hline
\end{tabular}

Block 3

\begin{tabular}{|l|l|l|l|}
\hline H & C & GWI & G \\
\hline BWI & HWI & B & CWI \\
\hline
\end{tabular}

2000 Design

Block 1

\begin{tabular}{|l|l|l|l|l|l|l|}
\hline C & BWI & RBWI & G & RG & H \\
\hline B & RB & GWI & RGWI & CWI & HWI \\
\hline
\end{tabular}

Block 2
\begin{tabular}{|l|l|l|l|l|l|l|}
\hline CWI & HWI & H & B & RB \\
\hline GWI & RGWI & C & G & RG & BWI & RBWI \\
\hline
\end{tabular}

Block 3

\begin{tabular}{|c|c|c|c|c|c|c|}
\hline $\mathrm{H}$ & & C & GWI & RGW! & G & $R G$ \\
\hline BWI & RGWI & HWI & $B$ & $\mathrm{RB}$ & $\mathrm{CV}$ & \\
\hline
\end{tabular}

Key: B- burn, BWI- burn with inoculation, C- control, CWI- control with inoculation, G- graze, GWI- graze with inoculation, $\mathrm{H}$ - herbicide, HWI- herbicide with inoculation, RB- reburn, RBWI- reburn with inoculation, RG- regraze, RGWIregraze with inoculation

Figure 1. 1999 and 2000 study plot layout designs and individual treatment cell designations.

and mixed-grass systems of the northern Great Plains (Willson 1991). In areas where the presence of native grasses is either important, necessary, or mandated, knowledge of how to control this aggressive species is vital.

In the past, smooth brome has been planted in borrow pits and road corridors in Wyoming as a reclamation practice. Regulatory agencies such as the Wyoming Department of Environmental Quality, Land Quality Division (WDEQLQD), have mandated use of native species and control of introduced species on many types of reclaimed lands under their jurisdictions. Smooth brome invasion of reclaimed areas is now recognized as a problem requiring research to identify efficient and effective control methods that will not harm existing native cool- and warm-season plant communities.

Previous control method research has been directed in ecosystems typically having warm-season grasses as the dominant component (Gates et al. 1982; Willson and Stubbendieck 1996). This project was located in northern Wyoming, situated in a mixed-grassland ecosystem where cool-season grasses were dominant. The efficacy of fire, grazing, and herbicide treatments designed to reduce smooth brome without negatively impacting seeded cool-season grasses was examined. Concurrently, the effectiveness of native soil inoculation as a growth enhancement technique for the seeded, native cool-season grasses was investigated. Respread topsoil had been stockpiled for 20 years, and, as a result, microbial content assessments indicated near-zero levels. The overall goal was to identify effective brome control methods that reduced competition while concurrently investigating microbial inoculation and associated beneficial effects of plant-microbe symbiosis. These treatments, in tandem, were expected to improve performance of seeded, native cool-season grasses.

\section{MATERIALS AND METHODS}

\section{Study Site}

The Pittsburg \& Midway Ash Creek Mining Company’s PSO \#1 mine permit area is located in Sheridan County in north-central Wyoming, approximately $22 \mathrm{~km}$ northeast of Sheridan, Wyoming (lat $45^{\circ} 59^{\prime} 54^{\prime \prime} \mathrm{N}$, long $\left.106^{\circ} 54^{\prime} 08^{\prime \prime} \mathrm{W}\right)$. The mine site lies on the western edge of the Powder River Basin and the eastern edge of the Big Horn Mountain uplift, occupying approximately 185 ha at an average elevation of $1143 \mathrm{~m}$. The site has a semiarid climate typical of the continental steppe of the northern Great Plains. Average annual daily maximum and minimum temperatures are $14.72^{\circ} \mathrm{C}$ and $-0.22^{\circ} \mathrm{C}$, respectively, with an overall monthly mean temperature of $7.10^{\circ} \mathrm{C}$. The mine site is located within the Natural Resource Conservation Service 25-35 cm northern Plains precipitation zone. The area receives more than half $(53 \%)$ of the annual mean precipitation from April through July and average annual wind speed is $13.0 \mathrm{~km} / \mathrm{h}$, predominantly from the northwest. Average growing season is 125 days (Pittsburg \& Midway Ash Creek Mine Permit \#407-T3).

Premine soils mapped on the permit area were dominated by aridisols and to a lesser extent entisols. The 1976 soil survey distinguished 2 horizons that were suitable for reclamation purposes. Topsoil was replaced to a depth of $60 \mathrm{~cm}$ on study sites after long-term storage (1976-1996) in large, deep stockpiles. The area is characterized as northern mixed-grass prairie with small inclusions of ponderosa pine (Pinus ponderosa Laws.) and Rocky Mountain juniper (Juniperus scopulorum Sarg.) forests or savannahs. Much of the region is dominated by Wyoming big sagebrush (Artemisia tridentata spp. wyomingensis Beetle and Young), with a herbaceous understory dominated by coolseason perennial grasses and a minor warm-season perennial grass component. Smooth brome was accidentally introduced in mulch after the site was initially seeded in 1997. After the first growing season, smooth brome was the dominant constituent of the new plant community. Precipitation in 1999 (371 mm) was near normal $(379 \mathrm{~mm})$; however, precipitation in 2000 was below normal $(233 \mathrm{~mm})$.

\section{Experimental Design}

Brome control treatments were designed to damage smooth brome perennating buds. In previous research, brome control measures often failed because of inadequate removal of perennating buds located close to the soil surface. Willson and Stubbendieck (1996) described the problem when using a mowing apparatus that failed to cut smooth brome to the predetermined $4-\mathrm{cm}$ stubble height. In this research, an attempt was made to exploit the natural vertical height difference between perennating buds of smooth brome and native grasses. Smooth brome buds were generally higher above the soil surface than seeded native grasses, including western wheatgrass (Pascopyrum smithii [Rydb.] A. Love), bluebunch wheatgrass (Pseudoroegneria spicata [Pursh] A. Love), and thickspike wheatgrass (Elymus lanceolatus [Scribn. \& J.G. Smith] Gould).

Plots were designated and marked in the fall of 1998 based on similarities in soil type and depth, topography, aspect, distance from native undisturbed areas, drainage, and uniformity of smooth brome cover. Replicate blocks were located within a reclaimed, smooth brome matrix, $100 \mathrm{~m}$ from the nearest undisturbed area with about a $100-\mathrm{m}$ buffer zone 
surrounding each block. The project was designed as a $4 \times 2$ factorial with repeated observations analyzed as a split plot in time, set in a randomized complete block design (RCB) with 3 replicate blocks $(20 \times 64 \mathrm{~m})$ each containing $8(10 \times 16 \mathrm{~m})$ cells (Fig. 1). Treatments included factor A, time; factor B, brome control method (burn, graze, herbicide); and factor C, inoculated or not inoculated with native topsoil. In 2000, the effects of a second season of burning and grazing were tested. Because of poor results and inherent hazardous nature, paraquat was not applied in 2000. Treatment cells were split into 2 categories: cells that were not retreated and cells that were retreated. Because of the unbalanced nature of the experiment following additional treatments in the second year, total microbial carbon, soil moisture, and mycorrhizal root infection were set as a $4 \times 2$ factorial, with repeated observations (months within years) analyzed as a split plot in time and arranged in an RCB design (Fig. 1). In the 2000 season, retreated cells were analyzed against themselves as well as the cells that were not retreated. However, percent foliar cover and aboveground biomass data were collected at the time of peak production ( 1 sampling period) and subsequently analyzed as a standard analysis of variance set in a $4 \times 2$ factorial arranged in an RCB: factor A, brome control treatment, and factor B, inoculated or not inoculated with native topsoil.

All statistical analyses were performed using the Statistical Analysis System (SAS Institute 2000). Percent foliar cover, soil moisture, and percent root infection were subjected to arcsine transformation before analysis was conducted; however, results are reported as percent values. All values are reported along with standard errors. Least Significant Difference (LSD) was used as a means comparison procedure. Statistical significance was determined at $P \leq 0.05$.

\section{Field Methods}

Treatments were applied in mid-May 1999, the actual time of smooth brome tiller elongation. Tiller elongation is the stage at which smooth brome is most susceptible to control method application (Willson and Stubbendieck 1996). Gramoxone Extra (paraquat) (1,1'-dimethyl-4,4'-bipyridimium dichloride), a nonselective, foliar applied herbicide, was applied at a rate of 0.5 pounds active ingredient per acre along with a nonionic surfactant and a drift-reducing agent using an ATV with a 10foot boom. Horses were used for the $60 \%$ utilization grazing treatment. Native undisturbed topsoil $(0-10 \mathrm{~cm}$ depth) was collected adjacent to test plots and spread using a hand-pushed lawn/garden fertilizer spreader for the inoculation treatment at a rate of approximately $538 \mathrm{~g} / \mathrm{m}^{2}$. Burning was performed using drip torches with the previous year's stubble $\left(1500 \mathrm{~kg} \cdot \mathrm{ha}^{-1}\right)$ serving as fine fuel. Atmospheric conditions at ignition time (0900) were $20^{\circ} \mathrm{C}$ with a $9.6 \mathrm{~km} / \mathrm{h}$ southwest wind. Burn was generally cool and of short duration.

Soil microbial biomass content was determined using 5 soil samples (20-50 g dry weight) from the top $6 \mathrm{~cm}$ of the soil from each treatment during the months of June, July, and August 1999 and 2000. Each of the 5 samples was treated as a subsample and combined to obtain a pooled sample for that month. Soil samples were placed in coolers with ice for transport from the field then stored at $4^{\circ} \mathrm{C}$ until lab analysis (Horwath and Paul 1994). The chloroform fumigation extraction method was used to estimate soil microbial biomass carbon content (Tate et al. 1988; Horwath and Paul 1994).

Soil moisture samples were collected every 7-10 days during the growing season in 1999 and 2000. Two subsamples were collected for each cell at 2 depths $(0-15$ and $15-30 \mathrm{~cm})$ using a soil corer. Soil moisture was obtained from field samples using standard gravimetric soil moisture analysis (Klute 1986). Five random root samples from each treatment cell $(0-10 \mathrm{~cm}$ depth) were collected using a shovel from both smooth brome and native cool-season grasses during June and August 1999 and 2000 to quantify mycorrhiza formation and placed in refrigerated storage before analysis using the methods of Rajapakse and Miller (1994).

Aboveground biomass was clipped at peak production in July 1999 and 2000 . Four $0.25-\mathrm{m}^{2}$ quadrats were randomly placed within each of the treatment cells and clipped to ground level (Mueller-Dombois and Ellenberg 1974). Vegetation was separated into 2 different categories: smooth brome and native cool-season grasses. Samples were dried at $60^{\circ} \mathrm{C}$ for 24 hours and weighed to determine dry weight. Percent foliar cover was determined using a 10-point pin frame at 10 randomly selected points within each treatment cell (Heady and Radar 1958).

\section{Laboratory Methods}

Soil samples were sieved through a 2-mm screen (Jenkinson and Powlson 1980). Total microbial biomass carbon was determined using the chloroform fumigation-extraction method (Voroney and Paul 1984; Tate et al. 1988; Horwath and Paul 1994) using a $K_{c}$ of 0.35 and analyzed with a Shimadzu 5000 total organic carbon gas analyzer.

Smooth brome and native grass roots were prepared for microscopic observation by washing in distilled water, clearing in $10 \%$ potassium hydroxide $(\mathrm{KOH})$, stained in lactoglycerol (1:1:1 85\% lactic acid:distilled water:glycerin) containing trypan blue $(0.066 \%)$. Roots were cleared following staining using clear lactoglycerol (Phillips and Hayman 1970). Roots were microscopically observed, and mycorrhizal colonization was quantified using the method of Allen and Allen (1980).

\section{RESULTS AND DISCUSSION}

\section{Aboveground Biomass and Foliar Cover}

At peak production of the 1999 growing season, smooth brome and native grass regrowth was significantly reduced by brome control treatments $(P<0.0001$ and $P=0.006$, respectively). Results are shown in Table 1 . Smooth brome biomass was lowest in grazed cells $\left(250 \pm 84 \mathrm{~kg} \cdot \mathrm{ha}^{-1}\right)$ followed by herbicide (383 \pm 91 ), burning (431 \pm 129 ), and untreated (1 $368 \pm 236$ ). Native grass biomass production was also lowest in the grazed treatment $\left(33 \pm 24 \mathrm{~kg} \cdot \mathrm{ha}^{-1}\right)$ followed by herbicide $(59 \pm 60)$, burning $(61 \pm 58)$, and control $(195 \pm 60)$. The inoculation treatment provided no effect on smooth brome biomass but did influence native grass production $(P=0.04)$. Noninoculated cells $\left(125 \pm 71 \mathrm{~kg} \cdot \mathrm{ha}^{-1}\right)$ produced more biomass than inoculated cells $(78 \pm 33)$. No treatment interactions were indicated in any of the analyses.

Aboveground biomass treatments were split into retreated and not retreated for the 2000 growing season. There were no differences among brome control or between inoculation 
Table 1. Aboveground biomass production and foliar cover results and standard errors ( \pm ) for smooth brome and native grass by brome control treatment and year, 1999 and 2000.

\begin{tabular}{|c|c|c|c|c|c|c|c|c|}
\hline \multirow[b]{3}{*}{ Treatment } & \multicolumn{4}{|c|}{ Smooth brome } & \multicolumn{4}{|c|}{ Seeded grass } \\
\hline & \multicolumn{2}{|c|}{1999} & \multicolumn{2}{|c|}{2000} & \multicolumn{2}{|c|}{1999} & \multicolumn{2}{|c|}{2000} \\
\hline & $\mathrm{kg} \cdot \mathrm{ha}^{-1}$ & $\%$ cover & $\mathrm{kg} \cdot \mathrm{ha}^{-1}$ & $\%$ cover & $\overline{\mathrm{kg}} \cdot \mathrm{ha}^{-1}$ & $\%$ cover & $\mathrm{kg} \cdot \mathrm{ha}^{-1}$ & $\%$ cover \\
\hline Burn & $431 \pm 129$ & $33 \pm 13$ & $821 \pm 506$ & $44 \pm 11$ & $61 \pm 58$ & $6 \pm 4$ & $104 \pm 41$ & $7 \pm 5$ \\
\hline Graze & $250 \pm 84$ & $22 \pm 8$ & $785 \pm 159$ & $43 \pm 14$ & $33 \pm 24$ & $3 \pm 1$ & $141 \pm 67$ & $7 \pm 1$ \\
\hline Herbicide & $383 \pm 91$ & $20 \pm 10$ & $1114 \pm 450$ & $37 \pm 12$ & $59 \pm 60$ & $3 \pm 1$ & $72 \pm 30$ & $7 \pm 1$ \\
\hline Untreated & $1368 \pm 236$ & $45 \pm 5$ & $824 \pm 42$ & $41 \pm 8$ & $195 \pm 60$ & $4 \pm 1$ & $30 \pm 27$ & $4 \pm 1$ \\
\hline Reburn & & & $189 \pm 77$ & $32 \pm 8$ & & & $88 \pm 91$ & $12 \pm 8$ \\
\hline Regraze & & & $294 \pm 129$ & $28 \pm 3$ & & & $107 \pm 78$ & $9 \pm 3$ \\
\hline
\end{tabular}

treatments for smooth brome in untreated cells. However, retreated cells were different $(P<0.0001)$. Smooth brome biomass was lowest in reburned cells $\left(189 \pm 77 \mathrm{~kg} \cdot \mathrm{ha}^{-1}\right)$, followed by regrazed $(294 \pm 129)$, and the highest was observed in control cells $(824 \pm 42)$. No differences were found between inoculation treatments for smooth brome production. Similarly, no differences were observed among control or between inoculation treatments for native grass biomass production in 2000 untreated or retreated cells; however, the grazing treatment reduced native grass production the least (graze $141 \pm 67$, burn $104 \pm 41$, herbicide $72 \pm 30$, and untreated $\left.30 \pm 27 \mathrm{~kg} \cdot \mathrm{ha}^{-1}\right)$.

Foliar cover response (1999) of smooth brome was identical to biomass production results $(P=0.005)$. Smooth brome cover was lowest in the grazed treatment $(20 \pm 10 \%)$, followed by herbicide $(22 \pm 8 \%)$, burning $(33 \pm 13 \%)$, and control ( $45 \pm$ $5 \%)$. Inoculation had no effect on smooth brome cover. Native grasses were not influenced by either brome control or inoculation treatments. In 2000, brome control and inoculation treatments had no effect on smooth brome or native grass cover.

Grazing was generally the most effective brome control treatment but reduced native grass regrowth more than burning the first year. However, the opposite was true after retreatment the second year. Native grass regrowth was always lowest in cells with greatest smooth brome production and greatest in cells with the lowest. Overall, regrowth was less in 2000 than in 1999, indicating residual effects of the previous year treatments and lower precipitation in 2000. Our results were consistent with other studies demonstrating improved brome control with repeated applications of fire and mowing (Willson and Stubbendieck 1996, 1997). The proposed mechanism is destruction of growing points followed by a reduction in secondary tiller production due to lower carbohydrate reserves and photosynthetic tissues (Kunelius et al. 1974). Growth is gradually reduced as plant resources decline. If the process is continued over time and seeded grasses are not subjected to the same disturbance, we expect that the competitive balance will shift from smooth brome to seeded species.

\section{Soil Microbial Biomass, Soil Moisture, and Mycorrhizae Formation}

Microbial biomass results are displayed in Table 2. In the 1999 microbial biomass analysis, there were no differences among brome control, inoculation, or time treatments, and no interactions were detected. Untreated cells in 2000 also showed no difference among treatments. Retreated cells indicated a difference between months $(P=0.013)$, but brome control and inoculation treatments were not different. The lowest microbial biomass carbon across all treatments was estimated in June $(0.07 \pm 0.01 \mathrm{mg} / \mathrm{g})$, followed by July $(0.12 \pm 0.01)$ and August $(0.12 \pm 0.01)$.

The 1999 analysis indicated the herbicide treatment retained more soil moisture $(10 \pm 0.1 \%)$ than grazing and burning $(9 \pm$ $0.8 \%$ and $9 \pm 0.1 \%$, respectively) and untreated $(8 \pm 0.68 \%)$ $(P<0.0001)$ and that soil moisture at both depths decreased as the growing season progressed. Analysis of the 2000 growing season data indicated that time was the only significant treatment $(P<0.0001)$ in untreated and retreated cells at both depths, with soil moisture declining as the growing season progressed.

The decline in soil moisture as the growing season progressed was expected because of increased evapotranspiration, soil warming, and little precipitation. A highly developed root system of smooth brome compared to native grasses was observed. Smooth brome has an advantage over native plants because of this characteristic that enabled exploitation of the lower soil profile. The herbicide treatment retained the most soil moisture because of the decreased evapotranspiration and shading from ungrazed plants. Burn and graze treatments had

Table 2. Microbial biomass results and standard errors $( \pm)$ by brome control treatment, month, and year.

\begin{tabular}{|c|c|c|c|c|c|c|}
\hline \multirow[b]{2}{*}{ Treatment } & \multicolumn{3}{|c|}{$1999(\mathrm{mg} / \mathrm{g})$} & \multicolumn{3}{|c|}{$2000(\mathrm{mg} / \mathrm{g})$} \\
\hline & June & July & August & June & July & August \\
\hline Burn & $0.10 \pm 0.06$ & $0.06 \pm 0.01$ & $0.09 \pm 0.03$ & $0.08 \pm 0.01$ & $0.13 \pm 0.03$ & $0.14 \pm 0.05$ \\
\hline Graze & $0.11 \pm 0.07$ & $0.05 \pm 0.01$ & $0.09 \pm 0.04$ & $0.09 \pm 0.01$ & $0.18 \pm 0.06$ & $0.11 \pm 0.04$ \\
\hline Herbicide & $0.11 \pm 0.03$ & $0.05 \pm 0.02$ & $0.05 \pm 0.01$ & $0.07 \pm 0.02$ & $0.14 \pm 0.08$ & $0.12 \pm 0.02$ \\
\hline Control & $0.08 \pm 0.1$ & $0.07 \pm 0.04$ & $0.05 \pm 0.03$ & $0.08 \pm 0.02$ & $0.15 \pm 0.03$ & $0.12 \pm 0.02$ \\
\hline Reburn & & & & $0.06 \pm 0.02$ & $0.11 \pm 0.01$ & $0.14 \pm 0.01$ \\
\hline Regraze & & & & $0.05 \pm 0.02$ & $0.10 \pm 0.01$ & $0.12 \pm 0.04$ \\
\hline
\end{tabular}


higher soil moisture content than untreated cells because of lower transpiration potentials resulting from less leaf surface. During the second growing season (2000), no effect was detected between the brome control treatments and soil moisture. This was attributed to similar vegetation biomass and foliar cover productions.

Although moisture values were different among months, microbial biomass carbon values were not. Dunn et al. (1985) found that microbial populations decreased exponentially with increasing temperatures. Furthermore, they found that heterotrophic soil bacteria decreased as a function of soil moisture and temperature, which was not found in this study. However, Dunn et al. (1985) also indicated that microbial group responses to temperature differ significantly. More consistent with these results, Allen (1993) found that moisture did not affect reclaimed soil microbial populations in southwestern Wyoming. Data from 1999 indicated that as soil moisture decreased through the growing season, microbial biomass also decreased. Near the end of the growing season, soil moisture continued to decline; however, microbial biomass actually increased slightly. In 2000, as moisture declined, microbial biomass increased, finally decreasing in the latter part of the growing season.

In both 1999 and 2000, mycorrhizal colonization of grass roots was estimated and recorded twice during each growing season (June and August). Analysis indicated no differences among brome control, inoculation, or time treatments in 1999. Although brome control treatments and time in the untreated cells did not produce significant results in 2000, a positive response was observed in the inoculation treatment $(P=0.01)$. Results indicated that inoculated cells had greater mycorrhizal formation than noninoculated cells $(34 \pm 3 \%$ and $27 \pm 3 \%$, respectively). Retreatment in 2000 had no effect.

Mycorrhizal root colonization decreased as moisture decreased across the growing season in 1999. Previous research indicates that the opposite is more common since mycorrhizae formation tends to be lower when moisture is extremely high (Dunn et al. 1985; Claassen and Zasoski 1993). This can be attributed to the lack of need for a symbiotic relationship of plants with mycorrhizae. When moisture is not limiting, plants are able to acquire sufficient amounts of water on their own. Brome control practices and soil inoculation had no effect on mycorrhizal formation in 1999. In 2000 untreated cells, the only effective treatment was the native soil inoculation. Even though root infection was not different among months, the drier conditions in 2000 may have allowed for slightly higher infection rates within these particular cells. Retreated cells produced similar results.

The effect of taller vegetation within the untreated plots and its ability to trap airborne microbes were also of interest. Allen (1988) found that shrubs modify their microenvironment by modifying wind dynamics, leading to an increased amount of trapped snow and organic matter. Smooth brome was much taller in untreated cells than treated cells. Based on Allen (1988), we anticipated that untreated plots would have higher microbial biomass values than treated cells; however, no differences were found.

Increased microbial biomass later in the growing season could also have been influenced by the vegetation itself. In treated cells, plants could be allocating more energy to shoot production, limiting the amount of root exudates. Reduced exudates can hinder microbial biomass production until sufficient shoot production is established. When more photosynthetic activity began to occur in the latter months (July and August) coincident with increased root exudates, the microbial community may have responded with an increase in productivity.

Native soil inoculation resulted in no increase of soil microbial biomass carbon. This is probably due to factors other than propagule density controlling microbial activity and biomass production in disturbed soil. A review of the literature showed the microbial community can reestablish in a timely manner (Allen et al. 1980; Visser et al. 1984; Stahl et al. 1988; Allen et al. 1989; Constantinidou et al. 1990; Allen and Allen 1992; St. John 1998). Not only is the microbial community able to reestablish itself by self-propagation (Allen and Allen 1992), but other sources, such as wind, rain, and animal vectors, are also capable of enhancing reestablishment. Constantinidou et al. (1990) found the deposition of bacteria to be 30-80 times greater during rain compared to no rain. Warner et al. (1987) and Allen et al. (1989) found that wind could disperse microbes up to $2 \mathrm{~km}$ distance from a source. If a nearby source of inoculum is present (e.g., undisturbed soil), populations of soil microorganisms will probably be augmented. Claassen and Zasoski (1993) also demonstrated similar results in areas treated with small amounts of topsoil as an inoculum source.

\section{CONCLUSIONS}

The most cost-effective means of initial smooth brome control in a native, cool-season grassland would be to heavily graze the area for several years while monitoring effects on both smooth brome and native grasses. This 2-year study demonstrated initial efficacy of the method. Burning is also an alternative but requires additional inputs and permits and may not always be feasible. Results also indicate that mycorrhizal inoculation did not enhance seeded, native grass production on stockpiled topsoil subjected to long-term storage.

\section{LITERATURE CITED}

Allen, E. B., And M. F. Allen. 1980. Natural re-establishment of vesiculararbuscular mycorrhizae following strip mine reclamation in Wyoming. Journal of Applied Ecology 17:139-147.

ALLEN, M. F. 1988. Belowground spatial patterning: Influence of root architecture, microorganisms and nutrients on plant survival in arid lands. $I n$ : E. B. Allen [ed.]. The reconstruction of disturbed arid lands: an ecological approach. Boulder, C0: Westview Press. p 113-135.

ALLEN, M. F. 1993. Microbial and phosphate dynamics in a restored shrub steppe in southwestern Wyoming. Restoration Ecology 1:196-205.

Allen, M. F., and E. B. Allen. 1992. Development of mycorrhizal patches in a successional arid ecosystem. In: D. J. Read [ed.]. Mycorrhizae in ecosystems. Wallingford, UK: CAB International. p 164-170.

Allen, M. F., L. E. Hipps, and G. L. Wooldridge. 1989. Wind dispersal and subsequent establishment of VA mycorrhizal fungi across a successional arid landscape. Landscape Ecology 2:165-171.

Claassen, V. P., and R. J. Zasoski. 1993. Enhancement of revegetation on construction fill by fertilizer and topsoil application: effect on mycorrhizal infection. Land Degradation and Rehabilitation 4:45-57.

Constantinidou, H. A., S. S. Hirano, L. S. Baker, and C. D. Upper. 1990. Atmospheric dispersal of ice nucleation-active bacteria: the role of rain. Phytopathology 80:934-937. 
DibBern, J. C. 1947. Vegetative responses of Bromus inermis to certain variations in the environment. Botanical Gazette 109:44-58.

Dunn, P. H., S. C. BarRo, AND M. РотH. 1985. Soil moisture affects survival of microorganisms in heated chaparral soil. Soil Biology and Biochemistry 17:143-148.

Gates, R. N., D. K. Schmidt, and S. S. Waller. 1982. Response of Bromus inermis (Leyss.) to spring burning. Proceedings of the Nebraska Academy of Science 92:10-11.

Heady, H. F., and L. Radar. 1958. Modifications of a point frame. Journal of Range Management 11:95-96.

Horwath, W. R., and E. A. Paul. 1994. Microbial biomass. In: R. W. Weaver, S. Angle, P. Bottonley, D. Bexdicek, S. Smith, A. Tabatabai, and A. Wollum [eds.] Methods of soil analysis, part 2: Microbiological and biochemical properties. Madison, WI: Soil Science Society of America. p 753-773.

Jenkinson, H. F., AND D. S. Powlson. 1980. Measurement of microbial biomass in intact cores and in sieved soil. Soil Biology and Biochemistry 12:579-581.

Kunelius, H. T., L. B. Macleod, and F. W. Calder. 1974. Effects of cutting management on yields, digestibility, crude protein, and persistence of timothy, bromegrass, and orchard grass. Canadian Journal of Plant Science 54:55-64.

KLUTE, A. 1986. Water retention: laboratory methods, In: A. Klute [ed.]. Methods of soil analysis, part 1: Physical and mineralogical methods. Madison, WI: Soil Science Society of America. p 635-662.

Mueller-Dombois, D., and H. Ellenberg. 1974. Aims and methods of vegetation ecology. New York: John Wiley and Sons.

PhiLLIPS, J. M., AND D. S. HAYMAn. 1970. Improved procedures for clearing roots and staining parasitic and vesicular-arbuscular mycorrhizal fungi for rapid assessment of infection. British Mycological Society Transactions 55:158-160.

RAJAPAKSE, S., AND V. C. Miller. 1994. Methods for studying vesicular-arbuscular mycorrhizal root colonization and related root physical properties, In: V. R. Norris, D. Read, and A. K. Varma [eds.]. Techniques for mycorrhizal research. London: Academic Press. p 761-776.
SAS Institute. 2000. SAS/STAT user's guide. 6.03 ed. Cary, NC: SAS Institute.

ST. JoHN, T. 1998. Mycorrhizal inoculation in habitat restoration. Land and Water 42:17-19.

Stahl, P. D., S. E. Williams, and M. Christiansen. 1988. Efficacy of native vesicular arbuscular mycorrhizal fungi after severe soil disturbance. New Phytology 110:347-354.

Stubbendieck, J., S. L. Hatch, and C. H. Butterfield. 1994. North American range plants. 4th ed. Lincoln, NE: University of Nebraska Press.

Tate, K. R., D. J. Ross, and C. W. Felthan. 1988. A direct extraction method to estimate soil microbial biomass $\mathrm{C}$ : effects of some experimental variables and some different calibration procedures. Soil Biology and Biochemistry 20:329-355.

Visser, S., J. Fujikawa, C. L. Griffiths, and D. Parkinson. 1984. Effect of topsoil storage on microbial activity, primary production, and decomposition potential. Plant and Soil 82:41-50.

Voroney, R. P., and E. A. Paul. 1984. Determination of $K_{c}$ and $K_{n}$ in situ for calibration of the chloroform fumigation incubation method. Soil Biology and Biochemistry 16:9-14.

Warner, N. J., M. F. Allen, and J. A. MacMahon. 1987. Dispersal agents of vesicular-arbuscular mycorrhizal fungi in a disturbed arid ecosystem. Mycologia 79:721-730.

WILLSoN, G. D. 1991. Morphological characteristics of smooth brome to determine a prescribed burn date, In: D. D. Smith and C. A. Jacobs [eds.]. Proceedings of the 12th North American Prairie Conference, Cedar Falls, IA: University of Northern lowa. p 113-116.

Willson, G. D., and J. StubBendieCK. 1996. Suppression of smooth brome by atrazine, mowing, and fire. The Prairie Naturalist 28:13-20.

Willson, G. D., And J. StubBendieck. 1997. Fire effects on four growth stages of smooth brome (Bromus inermis Leyss.). Natural Areas Journal 17:306-312. 